171 SIGNE LETH GAMMELGAARD

Ph.d.-studerende i litteraturvidenskab

Göteborgs Universitet

\title{
FASTE PENGE OG FLYDENDE KØD \\ Materialitet og neoklassisk økonomi \\ i Zolas Nana og Penge
}

Émile Zolas roman Penge (1891) hører ikke traditionelt til blandt hans mest kendte værker, og Zola-forskeren Brian Nelson kalder den tørt for "kunstnerisk uinteressant og temmelig tung" (158). Til gengæld synes den at have fået fornyet relevans siden krisen i 2008, og skal man tro en anden forsker på dette felt, Christophe Reffait, så læste man på Frankrigs berygtede 'classes prépas scientifique' netop denne roman i 2010 (57). Romanen skitserer kort fortalt superspekulanten Saccards storhed og fald gennem grundlæggelse og krak af hans 'Universalbank'.

Bagtæppet for Rougon-Macquart, som Penge er attende bind af i skriverækkefølge, er det andet franske kejserrige, som løber fra 1852 til 1870, men det historiske forlæg, Union Générale-krakket, sker i 1882. Samme periode, nærmere bestemt i 1870'erne, ser fødslen af neoklassisk økonomi med det, der betegnes den marginale revolution anført af W. Stanley Jevons, Carl Menger og Léon Walras. Ifølge disse sker værditilskrivning på markedet som en afstemning af forskellige parters nytte-beregning, til forskel fra den tidligere arbejdsværdi-tradition, hvor værdien skabes i produktionen. Den klassiske tradition tæller navne som Adam Smith og David Ricardo, og selvom Marx i høj grad forholder sig kritisk til den tidligere skole af politisk økonomi, så er arbejdsværdi-begrebet en hjørnesten i også sidstnævntes 
172 KULTUR \& KLASSE * $124 * 2017$

HANDEL

teori. Dette skifte er mit fokus i denne artikel, nærmere betegnet hvordan det finder vej ind i Zolas skildringer af samfund, subjektivitet og økonomiske dynamikker i to af hans romaner, nemlig førnævnte Penge og den mere kendte Nana (1880); i særlig grad vil jeg argumentere for, at den nye tænkning forplanter sig til hans romaner som opløsning og fluiditet, både på plotmæssigt, moralsk og æstetisk niveau. I begge romaner spiller handel en væsentlig rolle i form af værditilskrivning gennem selve transaktionen. 'Varens' cirkulation og den hastighed, den sker med, er helt afgørende for den ændring i værdi, som forekommer, og derfor er handlens egenart, udvekslingen, altså af stor betydning her, ligesom den er det i den marginale revolutions teorier.

Trods Zolas svaghed for forfaldshistorier er det dog ikke nogen entydig fordømmelse af denne nye økonomi, der finder sted. Zola virker snarere interesseret $\mathrm{i}$ at undersøge dens effekter, sådan som også hans naturalistiske metode foreskriver. Men der er måske alligevel en advarsel eller løftet pegefinger at spore i beskrivelsen af det begærets amokløb, der karakteriserer begge romaner. Den nye økonomiske tænkning baner nemlig vejen for et begreb om økonomisk rationalitet, der tager konkret form i figuren homo economicus. Det er en figur, der ifølge litteraten Regenia Gagnier er karakteriseret ved umætteligt begær, og netop dette er en væsentlig drivkraft både for Saccard og for Nana (144).

Trods Zola-forskningens ganske store fokus på penge og økonomi, så er konteksten med den marginale revolution vagt beskrevet. Filosoffen Jean-Joseph Goux udgør en undtagelse, som jeg trækker på i denne artikel, men da Goux snarere sigter mod at bruge Saccard som frontfigur for et generelt paradigmeskifte end at læse Zola, berettiger hans sparsomme læsning en udbygning. Goux fokuserer på tegn og betoner, at den neoklassiske økonomi indvarsler et skifte, hvor værdier (bredt forstået) er flydende og mobile, og soliditeten forsvinder, "alt fast og solidt fordufter", som Marx skrev allerede i 1848. Men Zolas romaner har også en stærkt materialistisk dimension, og i det følgende vil jeg derfor se på, hvad der sker med denne i konteksten af de marginale teorier. I min analyse lægger jeg således vægt på forholdet mellem fast og flydende, og læsningen af Nana ser på dobbeltheden i Nana som kød og Nana som værdi, eksemplificeret skarpest ved den gennemgående kobling til guld, som karakteriserer hende. I denne roman 
beskrives opløsningen af samfundet gennem en stærk drift mod kødet og mod dyriske lyster, som giver et interessant modspil til den overdrevne abstraktion og likviditet, vi ser i Penge, og hvis mekanismer også findes i Nana. I læsningen af Penge fokuserer jeg omvendt på ønsket om at omgå eller helt fjerne varens materialitet og på Saccard som tegn-manipulator, tal-magiker og poet overfor Gundermann og dennes mere gammeldags forhold til det materielle og det faste. Slutteligt diskuterer jeg Goux' tese om, at naturalismen i sig selv repræsenterer en form for fasthed, det han kalder et guldsprog, op mod David Baguleys læsning af naturalismens entropiske vision og peger her på dekadente og flydende elementer også i selve den æstetiske form.

\section{GULD OG KøD}

Nana er nummer ni i Zolas romancyklus, Les Rougon-Macquart. Den fortæller historien om pigen af samme navn, som trods tarvelige kår vokser op og bliver Paris' baldronning, en kurtisane, som til sidst har alle byens mænd i sin magt, og som undervejs tilraner sig større og større formuer. Ved bogens start debuterer hun på varieté-teatret, hvis direktør insisterer på at kalde det et bordel. Hun er hverken kløgtig eller dygtig, hendes eneste ressource er faktisk hendes krop, eller måske mere præcist hendes kød og hendes lyst. For i Nana hersker kødet, kødelige lyster såvel som kød på konkret og sprogligt niveau. Kød kan ses som det primære symbol på materialitet, og Nana selv præsenteres i første kapitel som "sejrsstolt i kraft af sit marmorhvide legeme [chair de marbre] og sit køn, der var stærkt nok til at lægge hele denne verden øde, uden selv at blive mærket deraf" (Zola, Nana 30). ${ }^{1}$ Lys og luft bliver også til kød i nogle iøjnefaldende formuleringer: "et vindue med gule og røde ruder oplyste den brede trappe med et blegt kødfarvet lys" (264), "Det så ud, som om en kødelig vind ude på gaden havde fejet alt fra en død tidsalder bort fra denne flotte, gamle bolig" (336), og i en af bogens sidste scener beskrives selv himlen som kødfarvet: "Værelset strålede i hele sin ny kongelige overdådighed. Det var betrukket med rosenrødt fløjl i den kødfarvede tone, som himlen antager på smukke aftener" (379).

1 Hvor der ikke er angivet andet, citeres der fra den danske oversættelse, 1979. 
174 KULTUR \& KLASSE * $124 * 2017$

HANDEL

Beslægtet med den kødelige tematik er termen bête, som optræder overalt i bogen, og som betyder både dyriskhed, bestialitet og dumhed. Dyremetaforik er ligeledes gennemgående, men interessant nok er Nanas to centrale dyremetaforer koblet med guld; hun beskrives dels som en destruktiv guldflue og "gulduhyre", dels allegorisk gennem en væddeløbshest, der deler hendes navn, og som lyser "som en nyslået guldmønt" (316). Sammen med romanens kødelige og dyriske tematik beskrives Nana altså fortløbende med guld som ledemotiv, i særdeleshed via hendes gyldne hår, som både indleder og afslutter fortællingen. Da Nana første gang ses på scenen i det bordel-teater, hvor hun arbejder, fremhæves hendes "svulmende barm, dækket af store gyldne smykker" og de "gyldne hår i hendes armhuler" (17), og da hun på allersidste side ligger død på et hotelværelse, står der: "på dette rædselsfulde og groteske billede af tilintetgørelsen havde håret, Nanas smukke hår, bevaret sin solglans og bølgede i en gylden strøm" (400). Selv når Nana til sidst rammes af ødelæggelsen, forbliver guldet uberørt, og det peger på guldets særlige økonomiske historie, på en gang tegn og materialitet, almen ækvivalent og ultimativ vare. ${ }^{2}$ Nana 'cirkulerer' i ekstrem grad, men hun mærkes ikke af det; den sygdom, der slår hende ihjel, skyldes smitte fra hendes søn. Som guldet er hun både en materiel vare, der i sig selv har værdi, og en 'aktie', der spekuleres i af hendes teaterdirektør-alfons (Duffy 156-163). Og netop som i spekulation øger Nanas cirkulation hendes værdi; jo flere mænd hun har, jo større formuer sluger hun fra dem hver.

Et særligt interessant eksempel på cirkulationens funktion er hen mod romanens slutning, hvor den lille 'kerub', Georges, Nanas yngste elsker, har begået selvmord og efterladt et blodspor på Nanas tæppe. Grev Muffat, der længe tror, han er Nanas eneste herre, har erkendt, at han blot er en blandt mange. Han frygter blodsporet, "kunne mod sin vilje ikke lade være med at studere det nøjere: jo lysere den røde farve blev, jo flere mænd havde passeret hen over det" (Zola, Nana 376-377). Jo hurtigere cirkulation, desto mere utydeligt bliver 'blodsporet', den materielle aflejring af begærets pris forsvinder i takt med, at Nana øger sin værdi og indtjening såvel som

2 Nelson læser i øvrigt Zolas La Curée i forhold til netop de to motiver, guld og kød. Se kapitlet "La Curée: Speculation and dissipation". 
sit forbrug; mod slutningen æder Nana kæmpe-formuer, adelige såvel som børstjente, på få uger (373).

Guldet står som nævnt ikonisk og historisk set som en dobbelttydighed mellem vareøkonomien og pengeøkonomien. Det har dels en iboende værdi (i modsætning til eksempelvis papirpenge), dels en 'målende' funktion. Særligt dets uforgængelighed gør det velegnet til dette formål, for ligesom Nana kan guld cirkuleres nærmest uden at forgå. Guldstandarden giver en soliditet, en forankring i pengenes flydende domæne, hvor ord som likvider, currencies, flow og cirkulation dominerer. I bogen The Coiners of Language undersøger Goux forholdet mellem repræsentative litterære udtryk i realisme og naturalisme og ændringer i disse i starten af det 20. århundrede. Hans tese er, at skiftet væk fra repræsentativitet i fransk litteratur falder (omtrent) samtidig med, at Frankrig afskaffer guldstandarden, og både sprog og penge således bliver 'inkonvertible'; det bliver umuligt at ombytte ord til ting, penge til guld (The Coiners of Language) ${ }^{3}$ For Goux står Zola som repræsentant for guld-sproget, det stadigt konvertible, men han peger i en senere læsning på, at Saccard i Penge indvarsler et nyt paradigme med spekulanten som frontfigur. I essayet Frivolité de la Valeur undersøger han nemlig den marginale tænkning og argumenterer for at se børsen som vor tids tankemodel, hvor spekulanten simpelthen er inkarnationen af tidens filosofi (105-117; Smith 206). Han understreger, at "I spekulantens forestilling har spil-værdi erstattet substans-værdi" (110), i tråd med den neoklassiske økonomis teser. Goux citerer desuden Pierre-Joseph Proudhons (1809-1865) pjece om børsen, som kaldes for "kvintessensen af handel" ("Values and Speculations" 170), såvel som "det moderne samfunds monument par excellence" (Frivolité de la valeur 110). Følger vi således Goux og Proudhon, er den marginale tænkning og børsens tiltagende betydning et afgørende skifte for såvel moderniteten som for handlens rolle i den. Goux' læsning af Penge i Frivolité udgør kun en lille del af essayet, men centralt

3 Det er rimeligt at forholde sig kritisk til denne temmelig vidtrækkende tese, og der findes en del modeksempler. I kapitlet "The Gold Standard and Literature: Money and Language in the Work of Jean-Joseph Goux" gennemgår Ben Roberts nogle af disse og argumenterer for at se Goux' projekt i en større ramme mellem sprog og penge, snarere end at finde konkrete modeksempler til tesen (Roberts). 
i både denne og resten af bogen er konceptet omkring den 'mobile' eller flydende værdi, som i værdi-spillets delirium "afsporer enhver ide om solid værdi, om stabilitetsfornemmelse, om objektiv virkelighed, om pålidelig fremstilling, om sandhed" (111). I Goux' læsning er den naturalistiske form således stadig 'fast' i kraft af guld-sproget, mens Zola i sit sene forfatterskab vender blikket mod den flydende verden i det indhold, han behandler. Som jeg uddyber senere, er der dog også nogle markante træk ved denne såkaldte faste form, som peger på opløsning og fluiditet, således at de dekadente træk også påvirker æstetikken.

Børsen danner i denne periode ramme for et væld af litterære værker, både i og uden for Frankrig, og Penge er ifølge Renata Wasserman ligefrem eksemplarisk for disse (193). I bedste dokumentariske stil fremlægger Penge et regulært børsens økosystem; med de store fisk såvel som de småhandlende, med gældsinddriveren, de spillegale, mæglerne, kulissebørsen og i centrum altså spekulanten Saccard.

\section{TAL OG TEGN}

Romanen er fundamentalt set historien om et bankkrak, nemlig historien om kreditforeningen 'Universalbanken's leveår fra dens grundlæggelse til dens kollaps. Bankens stifter og direktør, Aristide Saccard, befinder sig ved bogens begyndelse i efterdønningerne af et fejlslagent investeringseventyr. Her refereres til en anden af bøgerne i Zolas cyklus, hvor Saccard også er hovedperson, nemlig bogen La Curée ('Rovet'), som handler om spekulationer på boligmarkedet under Paris' haussmannisering. Efter nederlaget i disse vender han i Penge blikket mod aktiemarkedet, og da han møder en iderig og idealistisk ingeniør, Hamelin, som har store planer for at 'civilisere' Mellemøsten, men som mangler den fornødne kapital, beslutter Saccard at oprette banken, dels for at understøtte og igangsætte projekterne, men primært for selv at vinde stort på det.

Centralt i fortællingen står Saccards fantasteri. Hans ukuelige vilje driver ham til at manipulere på mere og mere grov vis med Universalbankens aktiekurs, indtil den når den endelige værdi af 3000 francs, som er hans mål. Herefter begynder aktien at falde, og romanen iscenesætter krakket som en vældig kamp mellem to tunge børsspekulanter, Saccard 
versus Gundermann, den asketiske, logiske, tysk-jødiske pengepuger. ${ }^{4}$ Gundermann spiller baisse, han satser på, at priserne falder. Han oversvømmer derfor markedet og tvinger Saccard, der omvendt spiller hausse med forventning om opgang, til store opkøb uden dækning, for at undgå at aktiekursen falder. Dermed kommer banken til at eje en voldsom andel af sine egne aktier, uden at der ligger 'rigtige penge', endsige værdier eller produktion bag, og Hamelins (in)aktiviteter er belejligt henlagt til orienten. Værditilskrivningen har således en stærkt imaginær karakter, og Saccards arbejde består hovedsageligt i at bearbejde aktiehandlens tillid til Universalbanken. Han beskrives desuden flere gange som en finansiel poet, en "virkelig Digter, hvad det finansielle angår, Millionens Digter" (Zola, Penge 235). Vi har altså en parallel mellem sprog og penge, parret med at Saccard bearbejder signifianter, eller som Bell kalder aktien: "den universelle signifiants signifiant" (Models of power 131). Da Saccard til sidst arresteres, er det på grund af "irrégularités d'écritures" (Zola, Les Rougon-Macquart 340), som betyder både uorden i regnskabsbøgerne og bogstavelig talt uregelmæssigheder i skrifterne.

Overfor Saccards fantasteri står som nævnt Gundermann, og kontrasten mellem disse to er drivende for bogens plot. I kapitel tre, der følger Saccards sammenstykning af kapitalkonsortiet for banken, tager han, trods sin egen modvilje, hen til Gundermann for at høre, om denne skulle ønske at lægge navn og kapital til Saccards projekt. Gundermanns afslag er lige så illustrativt, som det er nedladende: "De vil ufejlbarlig komme til at spille fallit, for De er så ung, så hidsig i Tøjet, De har altfor megen Indbildningskraft" (Zola, Penge 100). Besøget hos Gundermann fremstiller desuden dennes fuldkomne imperium, hvor han beskrives som "Den store Bankier", en mand, "der havde mere at sige end selve Kejseren, og hvis Trone stod anderledes fast end Napoleons" (94), hans "vidstrakte, uindskrænkede Myndighed", hvor "hver Afvikling [var] et Slag, hvor han ufejlbarlig gik af med Sejren i Kraft af sin knusende Overmagt" (98). Videre fortælles,

4 Hans jødiske afstamning og de refleksioner, den giver anledning til hos Saccard, er iøjnefaldende og har dannet fokus for en mængde forskning, som læser økonomiens status sammen med religion, men skal ikke udvikles videre her. Se f.eks. Apter; D. Bell; Wasserman. For romanens religiøse metaforik mere generelt, se Andersen. 
178 KULTUR \& KLASSE * $124 * 2017$

HANDEL

hvordan han "ejede alle de Penge, han satte i omløb, at han i sin Kælder, i sine Kasser og Kister havde et uudtømmeligt Forraad, som han forsigtigt og snedigt handlede med, over hvilket han selv var Eneherskeren, der adlødes ved sit mindste vink, selv var med overalt, saa alt, hørte alt, bestemte alt. En Milliard i en saadan Mands Haand er en altformaaende Løftestang" (98). Omnipotens og omnivision understreger såvel Gundermanns gudelignende status, som hvorfor Saccards misundelse er så ubærlig, at den bliver til ukontrollabelt had og hævnlyst. Men omnipotensen er også interessant i den forstand, at Gundermann er (eller tror sig) hævet over markedets love i kraft af sin egen kapitale vægt og sin knusende logik.

Gundermann kendetegnes desuden af en næsten sygelig sparsommelighed og asketisme; han er allerede ved frokosttid dødtræt, thi han står op hver dag kl. 5 for at arbejde, før alle andre vågner. Han har "baade Leversyge og Nyrekolik" og indtager derfor udelukkende mælk, som han næsten ikke orker at drikke. Saccard undrer sig over, hvorfor han gider:

[...] føre dette Slaveliv, som ikke den usleste Tigger vilde taale, leve med hovedet proppet fuldt af Talstørrelser, bristefærdigt af utallige Bekymringer? Hvorfor vilde han puge alt det Guld op, puge det sammen, når han ikke engang turde købe et Pund Kirsebær af en Sælgekone paa Gaden, naar han ikke gad gaa ind paa en Knejpe med en smuk Pige, naar han ikke kunde nyde noget af alt, hvad Penge kan skaffe; naar han ikke engang havde Tid eller Frihed til at tage sig en Times Hvile. (99).

Alligevel gribes Saccard dog af en "hellig Rædsel ved synet af denne Skikkelse; ikke den klassiske Pengepuger, men den ulastelige Arbejder, uden kødelige Lyster eller Drifter, saa at sige ulegemlig [devenu comme abstrait] i sin sygelige Alderdom" (99).

Hvor Saccard fremstilles som den dynamiske fantast, der nyder og yder i én bevægelse, og for hvem bevægelsen selv er målet, er Gundermann altså den ubestridte hersker, den guddommelige, abstrakte logik, men som netop besidder denne magt i kraft af egenkapital; hans imperium er funderet på det "uudtømmelige Forraad", og det er netop dette (dog sammen med en fatal svig i Saccards rækker), der gør ham i stand til at overvinde Saccard i romanens slutning.

Saccard og Gundermann fremstår som to arketyper for pengegriskhed og spekulation, og dynamikken mellem disse er forbilledligt undersøgt 
i David F. Bells læsning i Models of Power: Politics and Economics in Zola's Rougon-Macquart. Bell slår til lyd for, at politik og økonomi hænger uløseligt sammen i Rougon-Macquart, og han følger Zolas præmis, nemlig at placere krakket små tyve år i tid før Union Genérale for at koble det med kejserriget. Dermed flyttes det ud af konteksten af den marginale tænkning, og der findes ikke belæg for at sige, at Zola beskæftigede sig direkte med denne. Det gør den dog ikke mindre interessant som bagtæppe for Zolas skildring. ${ }^{5}$

I essayet "The Calculation of Jouissance" analyserer Goux den marginale tænkning og fremhæver to borgerlige (bourgeoise) typer med udgangspunkt i to scenarier fra Marx. Den ene er perverst fokuseret på at akkumulere, den anden udelukkende optaget af forbrug:

I det første tilfælde fremstår kapitalisten som en fanatisk akkumulatør, som søger hverken brugsværdi eller jouissance, men bytteværdi for bytteværdiens skyld og produktion for produktionens skyld. Det andet tilfælde fremhæver forbrug og jouissance og den fandenivoldsk begærlige fantasi - alle underlagt markedets og produktionens imperativer. (Symbolic economies 209).

Beskrivelsen vækker genklang med Gundermann som den fanatiske pengepuger og Saccard som den fandenivoldske fantast, og selvom der ikke er et en-til-en-forhold mellem de økonomiske paradigmer før og efter den marginale revolution og disse to arketyper, så går bevægelsen hovedsageligt fra Gundermann mod Saccard. Her markeres netop det førnævnte skifte fra produktionsværdi til forbrugsværdi. I den klassiske politiske økonomi beror varens værdi, på hvilket menneskeligt arbejde der ligger bag produktionen. Marx' teser om denne er givetvis de mest kendte og da også dem, der refereres til i Penge gennem Marx-disciplen Sigismond Busch. Hos Marx er værdien (og ikke blot prisen) den mængde socialt arbejde, det har taget at producere varen. ${ }^{6}$ I den neoklassiske økonomi danner den marginale brugs-

5 Metodespørgsmål i forhold til Zola-forskning og -forskningstraditionen diskuteres desuden af Bell i forhold til Serres' berømte læsning af termodynamik som rammeværk for Les Rougon-Macquart. Særligt berøres spørgsmålet om direkte og indirekte citeringer af anden tænkning i Zolas samtid. Se D. F. Bell, "Serres's Zola"; Serres.

6 Ideen om arbejdsværdi hos Marx er både kompleks og omdiskuteret. Han skelner mellem nytteværdi, bytteværdi og så den egentlige værdi, som udtrykker arbejdsti- 
180 KULTUR \& KLASSE * $124 * 2017$

HANDEL

værdi centrum; det forhold, at værdien af noget aftager jo større mængde, der er til rådighed (Jevons pkt. 8). Værdien af en vare bestemmes således ud fra 'den sidste' af noget, altså marginalen, og den fastlægges gennem en forhandling mellem producent og forbruger, hvor begge parter opgør deres nyttekalkyle (baseret på smerte versus behag) og afstemmer dem i prisen. Producenten afvejer, hvor meget 'smerte' det har kostet ham at fremstille varen, forbrugeren overvejer, hvor meget behag den samme sum vil kunne skaffe ham andetsteds. For Jevons udtrykker markedspriser således den bedste måde at måle kvantitative effekter af smerte og behag, som ellers er svært målelige størrelser (Gallagher 126-127). Regenia Gagnier, som specialiserer sig i det britiske fin-de-siècle, fremhæver, hvordan dette har betydning for de to størrelser begær og knaphed; økonomi er videnskaben om knappe goder, fordi værdi afhænger af det sidst tilgængelige af noget, og den nye figur homo economicus er grundlæggende umættelig: "Med Jevons og Menger bliver umætteligt begær det definerende træk ved den moderne mand, umætteligheden snarere end hans rationalitet kommer til at adskille ham fra andre tider og andre racer mindre langt fremme på den evolutionære skala" (144). Det er Saccard i en nøddeskal, "han havde smagt paa alt, prøvet alt, men var aldrig bleven mæt" (Zola, Penge 7), og netop denne umættelighed er også Nanas fremmeste egenskab. Litteraten Catherine Gallagher betoner dog, at producenten ikke forsvinder ud af billedet i neoklassisk teori, men udgør en vigtig funktion i prisafstemningen (127). Ligeledes er ideen om nytte- og bytteværdi heller ikke fraværende i den klassiske politiske økonomi. Det centrale er således, at vægten mellem produktion og konsumption skifter.

Saccards paradigme svarer altså til det neoklassiske, Gundermanns er nærmere de gamle politiske økonomers. I den marginale tænkning har varen ikke længere nogen iboende værdi, da værdien kun er udtryk for den attrå, den genererer. Bells analyse i Models of Power betoner magten, både den økonomiske og den politiske magt, som en manipulation af signifianter, der følges af en abstraktionsproces væk fra varens materialitet. Han gen-

den. For Marx er det meget centralt, at arbejde er socialt og en fraktion af det, han kalder det abstrakte og socialt nødvendige arbejde. Værdien af en vare stiger altså ikke, fordi en langsom arbejder har produceret den (Marx sektion 1). For en rimelig enkel indføring i Kapitalen se Heinrich, særligt kapitel 3 om værdi og arbejde. 
nemløber Saccards mange strategier for at skabe begær efter den temmelig immaterielle vare, han tilbyder, nemlig aktien, og de fleste af disse er ret anløbne: En er at erhverve sig troværdige finansaviser og så gradvist placere tips og anbefalinger af Universalbanken i såkaldt objektive nyhedsartikler og derved skabe efterspørgsel; en anden består i at opkøbe sine egne aktier i en fuldstændig uhørt grad og derved skabe knaphed. Faktisk er Saccards sidste våben at købe alle sine egne aktier via stråmænd, hvorved han kan skabe fuldstændig knaphed på markedet, såvel som 'presse' de spekulanter (herunder Gundermann), som har 'shortet' hans aktier (dvs. solgt en aktie, de endnu ikke ejer, til levering på en fastsat fremtidig dato med håb om et fald i prisen inden da). Denne plan virker dog kun, hvis der er fuld tiltro til banken, så da Saccard stikkes af sin spillegale elskerinde, ramler planen. Hvis signifianten, aktien, er absolut selvberoende og afkoblet fra signifiéen, giver det således Saccard total magt, men også, som Bell påpeger, total skrøbelighed. Han definerer spekulation med afsæt i Marx som:

Et forsøg på at omdanne den produktive udvekslingsproces repræsenteret ved cyklussen vare-penge-vare, til en spejlende proces repræsenteret ved cyklussen penge-vare-penge. Denne nye cyklus gav anledning til en stadigt hurtigere omsætning, som nødvendiggjorde visse strategier for at omgå varens materialitet. (Models of power 126).

Spekulation beror på øget cirkulation og hastighed, og jo 'længere fra' varens materialitet, jo lettere er det at opnå denne øgede cirkulation.

Trods Saccards afsluttende fiasko, så løber der gennem bogen en diskurs omkring pengenes produktivitet. Flere steder, herunder på allersidste side, kaldes de for "gødning", altså både lort og livgiver. Generelt i forskningen tilskrives Penge en optimistisk tone, som peger på farerne ved den nye finansøkonomi, snarere end at fordømme den helt og holdent (Andersen; Grenier; Wasserman). I sidste kapitel hører vi da også, at Saccard er i Holland, "atter i Færd med et kæmpemæssigt Foretagende" (Zola, Penge 425). Trods hans anden store fallit er han ustoppelig, evindelig på vej med nye planer. Bogen kan måske læses som en advarsel mod det fantasteri og bedrag, der følger med børsens logik, og nødvendigheden af at holde det i ave, men Zola selv betonede i sine skitser, at optimisme skulle være en grundtone i Penge. Han spejlede sig og sine holdninger i den mådeholdne karakter, 
182 KULTUR \& KLASSE * $124 * 2017$

HANDEL

Karoline, som, pudsigt nok, er bogens bedste økonom i sin etymologiske betydning af husholder, hvor hun hurtigt sparer Saccard en masse penge (Nelson 182-188). Netop Karoline lader sig forføre af Saccard, ender med at elske ham og overtager da også diskursen om spekulationens frugtbarhed, så nogen dødsdom over finanskapitalismen er Penge ikke. Højst en løftet pegefinger, en påmindelse om fornuftens mådehold og den nye tids farer.

\section{LIKVIDT KøD}

Selvom Nana er skrevet i 1880 og Penge først 11 år senere, så foreslog Zola selv at læse dem i omvendt rækkefølge. Det moralske forfald tilskrives det andet kejserriges tidsånd snarere end den, Zola selv skrev i. Men samtidig bliver Zolas senere romaner ifølge Nelson mere generelle og mindre aktuelle, som kejserriget glider ind i fortiden (158). Zolas dokumentariske strategi, baseret på rige feltstudier, markerer også, at teatret i Nana såvel som børsen i Penge har sit forlæg i Zolas samtid. Det interessante er dog, at den destruktion og forfaldet, som Nana afbilder, i den interne kronologi kommer efter bankkrakket; at kødets vælde efterfølger abstraktionens kollaps, dog stadig med kraftig betoning af cirkulationens logik.

I Penge sigter Saccard mod en fuldstændig afkobling fra den materielle vare og virkelighed, mens Gundermann stadig vil sidde solidt oven på sine pengebeholdninger. Gundermann tror desuden på en iboende værdi i aktien, "som ikke maa overskrides, og naar dette ved Publikums Begejstring sker, saa er Opgangen kunstig" (Zola, Penge 283). Gundermanns forhold til aktier er således også beslægtet med den gamle skole af politisk økonomi, hvor et forhold udenom markedsprisen fastlægger værdien. Han er selv den utrættelige arbejder, og snarere end finansmand kalder han sig for købmand (Zola, Penge 97-98). Hans paradigme er arbejdets, og derfor har han heller ikke behov for Saccards manipulationsstrategier, han er stadig i den 'faste' verden. Som Bells analyse dog viser, så bliver Gundermann efterhånden næsten lige så spillegal som Saccard i sin lyst til at vinde kampen og satser umådelig store summer på nedgangen, før han endelig sejrer.

Saccard såvel som Nana har derimod et ganske andet forhold til det materielle. Han beskrives som en nyder, men faktisk viser romanen ham ikke nyde synderligt meget. Det fremhæves, at han ikke er i stand til at holde 
på penge, "altid havde Løgn og Bedrag boet i hans Pengeskab og Guldet sivet ud af en Læk, han aldrig kunne finde" (Zola, Penge 7). For Saccard er det bevægelsen af pengene, fluiditet, ikke opsparingen af goder, og som vi har set Goux pege på, følger løgn og flydende værdier hinanden tæt.

Både Saccard og Nana bruger varerne til at symbolisere velstand og dermed løfte deres markedsværdi. Saccards store ønske er et imposant hovedkvarter, som tydeligt viser Universalbankens succes. Nanas begær er ligesom Saccards umætteligt, men også kendetegnet ved, at alt, hvad hun får fingrene i, øjeblikkeligt mister hendes interesse: "Intet blev mellem hendes hænder, hun smadrede alt, noget blegnede, andet blev beskidt mellem hendes små hvide fingre; en dynge af navnløst skrald, forvredne laser og mudrede klude fulgte hende og betegnede hendes vej.". 7 Tingene forsvinder bogstavelig talt mellem fingrene på hende, hun tilegner sig det for at ødelægge det, men markerer også derved, at varens iboende værdi er af ringe betydning for hende; i stedet bruges den til en bestandig destruktiv cirkulation.

Et er således, at moral såvel som økonomiske værdier flyder, men vi ser altså også en opløsning på materielt plan, som peger frem mod dekadencens figurer. I naturalisme-forskeren David Baguleys Naturalist Fiction: The Entropic Vision tager han bolden op fra filosoffen Michel Serres' lidt tidligere tese om termodynamikken som rammeværk for Rougon-Macquart, nemlig i særdeleshed begreberne entropi og overophedning. I Baguleys udlægning forplanter dette sig til den naturalistiske beskrive-modus, som ikke kun, som Goux mener, peger på det faste, men i særdeleshed anvender impressionistiske træk, hvor farver og materialer flyder sammen i en sanselig flygtighed (191). Ifølge Baguley veksler den naturalistiske stil således mellem videnskabens og kunstens forsøg på at dominere og kategorisere en "truende materialitet" med en streng form, og så et tredje element: "romanforfatteren tout court underlægger den menneskelige ånd til dens [den truende materialitets] invaderende forurening" (194). I Penge optræder et karakteristisk eksempel på det sidstnævnte ved gældsinddriveren Madame Méchain, hvis korporlige fremtræden er mildt sagt excessiv: Hendes ansigt "vælter" ud af hatten, hendes "umaadeligt svære Bryst og den vatersotti- 
184 KULTUR \& KLASSE * $124 * 2017$

HANDEL

ge Mave så ud som om de skulde sprænge den grønne Popelinskjole", og hendes lædersæk er så propfuld, at hun næsten ikke kan slæbe den (Zola, Penge 18). Og I Nana finder vi denne underkastelse i den klaustrofobiske og kvælende tæthed, som i særlig grad følger Grev Muffats første møder med Nana; en tæthed, der gør ham ør og svimmel: "denne atmosfære, der var sammensat af den varme damp fra vandfadet og svampen, af essensernes skarpe duft og champagnens berusende syrlighed" (Zola, Nana 123).

Som beskrevet tidligere er Nana selv karakteriseret ved materialitet i form af kød, og hun kaldes for en "naturkraft, en ødelæggende bacille" (184). Elaine Scarry skriver i sin bog The Body in Pain at:

På særlige tidspunkter, når der er en legitimitetskrise i et samfund - altså når en central ide eller ideologi eller kulturel konstruktion ikke længere vækker en befolknings tiltro, enten fordi den er tydeligt fiktiv, eller fordi den af en eller anden grund har mistet sine normale former for substantiering - vil menneskekroppens rene materielle fakticitet blive brugt til at forlene denne kulturelle konstruktion med en aura af 'virkelighed' og 'vished' (14).

Man kan med en vis rimelighed anskue denne periode som en legitimitetskrise, både med Zolas brug af kejserrigets fald og med økonomiens vaklen; yderligere bliver værdier flydende og er ikke længere forankrede i en materiel realitet og standard, men i stedet et udtryk for aggregerede subjektive nyttekalkyler. Selvom Scarry skriver om menneskekroppen som torturobjekt, så peger den temmelig iøjnefaldende kødtematik i Nana på en lignende effekt, men betoner altså samtidig dette som en hævnende og destruktiv natur, hvor også det materielle, som skulle give soliditet, likviderer, opløser og opsluger. Mod slutningen af romanen stråler Nana "med fordoblet glans over Paris", og "et lille pust fra hendes læber forvandlede guldet til fin aske, som vinden hver time fejede bort" (Zola, Nana 349), mens smykker "ligesom smuldrede hen på bunden af skufferne" (350).

Dynamikken mellem det faste og det flydende og mellem tegn og materialitet i disse romaner peger således på en periode, hvor opløsning, cirkulation og fluiditet kendetegner den udvikling, der finder sted, og hvor selv den 'faste' materialitet smuldrer og flyder. Men det peger også på en tilsvarende fetishering af det materielle, der bruges til at signalere magt og værdi, og som har en fænomenal tiltrækningskraft. Den udvikling, som 
Goux beskriver, hvor det økonomiske tankesæt, der gør værdier til en forhandling, forplanter sig til moral og sprog, viser sig også i fremstillingen af det materielle, og den naturalistiske beskrivelse svinger mellem den distancerede, nøgterne betragtning, der har videnskaben som sit forbillede, og en nærmest excessiv og opslugende materiel verden, som i sig selv flyder ud og mister stabilitet.

Denne læsning af Zolas to romaner peger desuden på en mulig større sammenhæng mellem fin-de-siècle-kulturens æstetiske udtryk og de økonomiske skift, der sker i perioden. Førnævnte Regenia Gagnier undersøger sammenhængen i en engelsk kontekst og peger her på markedstænkningens betydning i Oscar Wildes tekster, hvor særligt det umættelige begær er centralt. I en dansk kontekst melder Herman Bangs Stuk (1987) sig som en oplagt kandidat til en lignende analyse, som endog forener miljøerne fra Nana og Penge gennem koblingen af teatret med finansverdenen. Analysen af Zola peger således frem imod en mulig forbindelse mellem den tilstræbte autonomi i kunst og litteratur, som karakteriserer perioden, og de økonomiske forhold, i særdeleshed hvilken ideologi, der præger økonomisk tænkning. Læsningen af disse indirekte koblinger fremhæver desuden, håber jeg, hvordan litteraturen er et oplagt sted at undersøge de økonomiske forholds fremtrædener og forbindelser til subjektivitet, begær og fantasi.

SIGNe LETh GAMMELGAARD. Ph.d.-studerende i litteraturvidenskab ved Göteborgs Universitet med et projekt om gæld i fransk og engelsk litteratur i sidste halvdel af 180o-tallet. I redaktionen på TFL - Tidskrift för Litteraturvetenskap. Har tidligere publiceret i bl.a Artnodes, Passage og TFL.

\section{SOLID MONEY AND LIQUID FLESH}

Materiality and neoclassical economics in Zola's Nana and Money

This article examines the dynamics of matter and signifiers in Zola's two novels Nana (1880) and Money (1891). Though Zola's novels are often read with a focus on capital and economics workings, the context of marginalist economics contemporaneous to Zola is only vaguely described. In drawing upon Jean-Joseph Goux's work on marginalism and Zola, this topic is addressed, and the article discusses desire, fluidity, scarcity, and value and relates this 
186 KULTUR \& KLASSE * $124 * 2017$

HANDEL

to the depiction of a disintegrating matter in Nana, and to the motifs of flesh and gold running through the novel. In the reading of Money, the focus is on reckless desire and imagination gone awry, and the push towards an increasingly disconnected abstraction that allows for rapid circulation of values. Here, the two main speculative duelists are seen as representatives of two economic paradigms, and the article finally discusses the depiction of materiality and the uses of this in the novels in the context of a society where values, in the words of Goux, are increasingly fluid and mobile.

\section{KEYWORDS}

DK: Zola; den marginale revolution; Jean-Joseph Goux; neoklassisk økonomi; børsen

EN: Zola; the marginal revolution; Jean-Joseph Goux; Neo-classical economy; the stock exchange

\section{LITTERATUR}

Andersen, Michael Høxbro. "Spekulationsfeber. Finansielle fiktioner i Émile Zolas 'Penge'". Passage - Tidsskrift for litteratur og kritik 2971 (2014): 97-109, 125.

Apter, Emily. "Speculation and Economic Xenophobia as Literary World Systems: The Nineteenth-Century Business Novel". French Global: A New Approach to Literary History. Red. Christie McDonald og Susan Rubin Suleiman. New York: Columbia University Press, 2010. 388-403.

Baguley, David. Naturalist fiction: the entropic vision. Cambridge: Cambridge University Press, 1990.

Bell, David F. Models of power: politics and economics in Zola's Rougon-Macquart. Lincoln: University of Nebraska Press, 1988.

Bell, David F. "Serres Zola: Literature, Science, Myth". MLN 944 (1979): 797-808.

Bell, Dorian. "Beyond the Bourse: Zola, Empire and the Jews". Romanic Review 102 3-4 (2011): 485-501.

Duffy, John Joseph. "On the Edge: The Logic and Rhetoric of Marginality in Zola's 'Rougon-Macquart' novels". Ph.D. Indiana University, 1995.

Gagnier, Regenia. "On the Insatiability of Human Wants: Economic and Aesthetic Man". Victorian Studies 362 (1993): 125-153.

Gallagher, Catherine. The Body Economic, Life, Death, and Sensation in Political Economy and the Victorian Novel. Princeton: Princeton University Press, 2008.

Goux, Jean-Joseph. Frivolité de la valeur: essai sur l'imaginaire du capitalisme. Paris: Blusson, 2000.

Goux, Jean-Joseph. Symbolic economies: after Marx and Freud. Ithaca, NY: Cornell University Press, 1990. 
Goux, Jean-Joseph. The Coiners of Language. Norman, OK: University of Oklahoma Press, 1996.

Goux, Jean-Joseph. "Values and Speculations: The Stock Exchange Paradigm". Cultural Values 12 (1997): 159-177.

Grenier, Jean-Yves. "Review of La Bourse dans le roman du second XIX e siècle. Discours romanesque et imaginaire social de la spéculation". Annales. Histoire, Sciences Sociales 652 (2010): 507-509.

Heinrich, Michael. An Introduction to the Three Volumes of Karl Marx's Capital. New York: Monthly Review Press, 2012.

Jevons, William Stanley. "Brief Account of a General Mathematical Theory of Political Economy". History of Economic Thought Articles 29 (1866): 282-287.

Marx, Karl. "Economic Manuscripts: Capital Vol. I - Chapter One". Marxist.org. https:// www.marxists.org/archive/marx/works/1867-c1/cho1.htm\#S1

Nelson, Brian. Zola and the Bourgeoisie: A Study of Themes and Techniques in Les Rougon-Macquart. London: Springer, 1983.

Reffait, Christophe. "La crise financière actuelle, selon les écrivains du XIX e siècle". Esprit (1940-) 3611 (2010): 57-72.

Roberts, Ben. "The Gold Standard and Literature: Money and Language in the Work of Jean-Joseph Goux". Culture, Capital and Representation. Red. Robert J. Balfour. London: Palgrave Macmillan, 2010. 132-147.

Scarry, Elaine. The Body in Pain: The Making and Unmaking of the World. Oxford: Oxford University Press, 1987.

Serres, Michel. Feux et signaux de brume, Zola. Paris: Figures Grasset, 1975.

Smith, Douglas. "Consumer Chronicles: Cultures of Consumption in Modern French Literature". Modern \& Contemporary France 201 (2012): 139-140.

Wasserman, Renata R. Mautner. "Financial Fictions: Emile Zola's L'argent, Frank Norris' The Pit, and Alfredo de Taunay's O Encilhamento". Comparative Literature Studies 383 (2001): 193-214.

Zola, Émile. Les Rougon-Macquart: histoire naturelle et sociale d'une famille sous le second Empire. 5. Red. Armand Lanoux. Paris: Gallimard, 1967.

Zola, Émile. Nana. København: Gyldendals Bogklub, 1979.

Zola, Émile. Nana. Paris: Garnier, 1994.

Zola, Émile. Penge: Roman. København: Politikens Trykkeri, 1903. 
188 KULTUR \& KLASSE * $124 * 2017$ HANDEL 